\title{
Effect of cultural conditions on the growth and linamarase production by a local species of Lactobacillus fermentum isolated from cassava effluent
}

\author{
Ilesanmi Festus Fadahunsi ${ }^{{ }^{*}}$ D, Nafisat Kemi Busari ${ }^{1}$ and Olumide Samuel Fadahunsi ${ }^{2,3}$
}

\begin{abstract}
Background: This study was designed to investigate the effect of cultural conditions on growth and production of linamarase by a local species of Lactobacillus fermentum isolated from cassava effluent. Isolation and identification of bacteria from cassava effluent were carried out using the culture-dependent method and polyphasic taxonomy, respectively, while screening for cyanide degradation, and the effects of cultural conditions on the growth and linamarase activity of $L$. fermentum were investigated based on standard procedures.

Results: A total of twenty-one bacterial isolates were obtained from cassava effluent, and isolate MA 9 had the highest growth of $2.8 \times 10^{10} \mathrm{cfu} / \mathrm{ml}$ in minimum medium, confirmed as safe, identified as Lactobacillus fermentum and selected for further study. The highest growth of $2.498 \mathrm{OD}$ and linamarase activity of $2.49 \mathrm{U} / \mathrm{ml}$ were observed at inoculums volume of $0.10 \mathrm{ml}$ at 48 -h incubation period, while optimum growth of $1.926 \mathrm{OD}$ and linamarase activity of $1.66 \mathrm{U} / \mathrm{ml}$ occurred at $\mathrm{pH} 5.5$. At $37^{\circ} \mathrm{C}$, the optimum growth of $0.34 \mathrm{OD}$ was recorded with the highest linamarase activity of $0.81 \mathrm{U} / \mathrm{ml}$ at $30^{\circ} \mathrm{C}$. However, the incubation period of $48 \mathrm{~h}$ stimulated an optimum growth of $3.091 \mathrm{OD}$ with corresponding linamarase activity of $1.81 \mathrm{U} / \mathrm{ml}$, while the substrate concentration of $400 \mathrm{ppm}$ favours a maximum growth of $2.783 \mathrm{OD}$ with linamarase activity of $1.86 \mathrm{U} / \mathrm{ml}$ at $48 \mathrm{~h}$ of incubation. The supplemented of $10 \mathrm{mM}$ calcium ions stimulated optimum linamarase activity of $2.65 \mathrm{U} / \mathrm{ml}$.
\end{abstract}

Conclusion: Lactobacillus fermentum could be used as starter culture in cassava fermentation for the production cassava-based product with reduced cyanide content.

Keywords: Cultural conditions, Production, Linamarase activity, Lactobacillus fermentum, Cassava effluent

\section{Background}

Linamarase (EC 3.2.1.21) along with its naturally occurring substrates, linamarin and lotaustralin, is found in a variety of edible plants such as cassava, lima beans and flax. It is a well-studied hydrolytic enzyme that has also been isolated from members of eukaryotes, bacteria, fungi and archaea. It hydrolyses linamarin to produce

\footnotetext{
*Correspondence: sanmifadahunsi@yahoo.com

${ }^{1}$ Department of Microbiology, Faculty of Science, University of Ibadan,

Ibadan, Oyo State, Nigeria

Full list of author information is available at the end of the article
}

$\beta$-D-glucopyranose and acetone cyanohydrin which are further degraded to acetone and hydrogen cyanide (HCN), respectively (Nartey 1968; Cooke 1978; Rolle 1998; Murugan et al. 2012; Nwokoro 2016). In the production of garri (a household West African food material flour), the enzyme plays an important role in the batchwise detoxification process of cassava fermentation and degradation of cyanogenic compounds to produce $\mathrm{HCN}$ which either dissolves readily in water or released into the air in a process known as cyanogenesis (Ikediobi and Onyike 1982; Kostinek et al. 2006). Microorganisms have also been documented to exhibit the ability to 
disintegrate cyanide-containing compounds into acetone cyanohydrins by producing linamarase (Nwokoro 2016). In addition, some phytopathogenic fungi like Fusarium solani are capable of degrading cyanide. However, biodegradation by bacteria is preferable because it shows considerable advantage since bacteria are more easily manipulated both at biochemical and at genetic levels (Okafor and Ejiofor 1985; Huertas et al. 2006; Abban et al. 2013; Ahaotu et al. 2013). Cyanide is a toxic chemical compound present in plants seeds, bitter almonds, apricots, peaches and inorganic salts such as sodium and potassium cyanides. In cassava tubers, cyanide is available in the form of cyanogenic glucosides, linamarin and lotaustralin which are major safety concerns among cassava consumers and processor (Dunstan et al. 1996). Cyanide is a widely known inhibitor of cellular energy generation that occurs during oxidative phosphorylation. It binds to a large enzyme of the inner mitochondrial membrane (cytochrome oxidase), thus preventing the transfer of electrons to molecular oxygen and generation of adenosine triphosphate (ATP) (Nelson and Cox 2005; Tefera et al. 2014). Intake of 50 to $100 \mathrm{mg}$ of cyanide has been observed to elicit poisoning which is fatal to humans, while long-time consumption of trace amounts has been implicated in the aetiology of tropical neuropathy, fibrocalculous pancreatic diabetes (FCPD), glucose intolerance coupled with iodine deficiency goitre and cretinism (Mathangi et al. 2000; Cardoso et al. 2005). Hitherto, it had been reported that most locally produced cassava-based products contain cyanide higher than the World Health Organization (WHO)-recommended safety level (Owuamanam et al. 2010). In this context, this research is aimed at investigating the effect of cultural conditions on the growth and linamarase production by a local species of Lactobacillus fermentum isolated from cassava effluent.

\section{Methods \\ Sample collection}

Cassava effluent was collected from different cassava processing plants around Agbowo axis in Ibadan, Oyo State, at 10:00am on 26 September 2019. The samples were collected aseptically in clean sterile bottles and transported to the Food Biotechnology Postgraduate laboratory, Department of Microbiology, University of Ibadan, Nigeria, for immediate isolation of bacteria.

\section{Isolation of bacteria from cassava effluent}

The sample was serially diluted by transferring $10 \mathrm{ml}$ of cassava effluent into $90 \mathrm{ml}$ of sterile distilled water, and $1 \mathrm{ml}$ from $10^{4}$ dilution test tube was transferred into sterilized Petri dishes. Sterile $20 \mathrm{mls}$ of De Man, Rogosa and Sharpe agar (MRS agar) with pH 5.5 and nutrient agar (NA) were poured one after the other into the Petri dishes (Harrigan and McCance 1966). The MRS plates were incubated at $37{ }^{\circ} \mathrm{C}$ for $24 \mathrm{~h}$ in an anaerobic jar, while nutrient agar plates were incubated aerobically. Discrete colonies that grew on the plates were counted and recorded as colony-forming unit per millilitre (cfu/ $\mathrm{ml}$ ). Representative colonies were selected and streaked repeatedly to obtain pure isolates which were maintained on MRS and nutrient agar slants in refrigerator for subsequent use.

\section{Screening for linamarase-producing bacteria}

Screening for linamarase-producing bacteria was carried out by inoculating differently a single pure colony of the bacteria isolated from cassava effluent into $10 \mathrm{ml}$ sterile MRS and nutrient broth in different test tubes. Incubation was done anaerobically at $37^{\circ} \mathrm{C}$ for $48 \mathrm{~h}$ in an anaerobic jar to generate a growing and activated inoculum suspension, while that of nutrient broth was done aerobically. One millilitre of the activated cells suspension was transferred differently into $100 \mathrm{ml}$ of sterile MRS and nutrient broth containing $100 \mathrm{ppm}$ of filter-sterilized potassium cyanide $(\mathrm{KCN})$ as the sole nitrogen source in a 250-ml Erlenmeyer flask placed on rotatory shaker for $48 \mathrm{~h}$ at $37^{\circ} \mathrm{C}$. One millilitre of the agitated suspension was pipetted and serially diluted to $10^{-8}$ dilution, and 1 $\mathrm{ml}$ was taken and differently plated on sterile MRS and nutrient agar plates. The MRS was incubated anaerobically at $37^{\circ} \mathrm{C}$ for $48 \mathrm{~h}$ in an anaerobic jar, while the nutrient media was incubated aerobically at the same time and temperature. Plates were examined for bacterial growth, and the observed colonies were counted physically to measure the growth/survival in cyanide environment. Representative colonies were selected and subcultured severally to obtain pure colonies which were stored on agar slants in McCartney bottles and kept in the refrigerator. The isolate with the highest growth was selected for further studies.

\section{Safety assessment test for bacteria Gelatinase test}

Gelatinase activity was investigated as described by Harrigan and McCance (1966). A 24-h-old culture was streaked on nutrient gelatin agar and inoculated anaerobically for $48 \mathrm{~h}$ at $37^{\circ} \mathrm{C}$ and flooded with $\mathrm{HgCl}_{2}$ solutions $\left(15 \% \mathrm{HgCl}_{2}\right.$ in $20 \% \mathrm{HCl}$, v/v). Clear zones surrounding colonies were noted for positive reaction indicating gelatin hydrolysis.

\section{DNase test}

The isolate was tested for the ability to produce deoxyribonuclease. This was carried out by streaking the isolate on DNase agar and incubated for $24 \mathrm{~h}$, and the plate was 
flooded with concentrated $\mathrm{HCl}$ (Harrigan and McCance 1966).

\section{Haemolytic activity}

Haemolytic test was carried out with nutrient agar supplemented with $5 \%$ sheep blood. The plates were inoculated aseptically and incubated for $48 \mathrm{~h}$ at $37{ }^{\circ} \mathrm{C}$ and examined for greenish colouration halos to confirm the production of $\alpha$-haemolysin which indicates partial haemolysis, while complete clear zone indicated the production of $\beta$-haemolysin (Akinjogunla et al. 2014).

\section{Characterization of the isolated bacteria}

The isolates were characterized and identified using phenotypic and molecular methods.

\section{Phenotypic characterization}

Phenotypic characterization was carried out using criteria such as gram staining, spore staining, indole, starch and gelatin hydrolyses, urease, methyl red, motility, catalase tests, citrate, oxidase tests, growth at $4 \%$ and $6 \%$ $\mathrm{NaCl}$ and sugar fermentation (Sneath 1986; Holt 1994; Cheesbrough 2006).

\section{Molecular characterization (16S rDNA method)}

It was done using $16 \mathrm{~S}$ rDNA gene sequence analysis with a base pair of 1100 bp as shown in Fig. 1. The forward primer used was 27F-AGAGTTTGATCCTGGCTCAG, and the reverse primer was 1492R-GGTTACCTTGTT ACGACTTT (Woo et al. 2002).

\section{DNA extraction}

Genomic DNA extraction of cultured bacteria was done with column-based Bacteria DNA Preparation kit, according to the manufacturer's protocol (JENA Bioscience). Bacteria cells were harvested from $500 \mu \mathrm{l}$ aliquot of bacteria culture using microcentrifuge at $15,000 \mathrm{~g}$ for $1 \mathrm{~min}$. The residual pellet was re-suspended in $300 \mu \mathrm{l}$ of buffer and $2 \mu \mathrm{l}$ of lysozyme solution. The mixture was homogenized by inverting several times and incubated at $37{ }^{\circ} \mathrm{C}$ for $1 \mathrm{~h}$. Re-suspended cells were recovered by centrifugation and lysed by adding $300 \mu \mathrm{l}$ of lysis buffer and $2 \mu \mathrm{l}$ RNase and $8 \mu \mathrm{l}$ proteinase $\mathrm{K}$ solution followed by incubation at $60{ }^{\circ} \mathrm{C}$ for $10 \mathrm{~min}$. The tube was cooled on ice for $5 \mathrm{~min}$, and $300 \mu$ binding buffer was added to the mixture and vortexed briefly. The mixture was cooled on ice for $5 \mathrm{~min}$ and centrifuged at 10,000 g for $5 \mathrm{~min}$. The supernatant was transferred directly into the spin column and centrifuged at $10,000 \mathrm{~g}$ for $1 \mathrm{~min}$ to trap the DNA. The trapped DNA was washed twice with washing buffer and was eluted with $50 \mu$ lelution buffer into a clean Eppendorf tube.

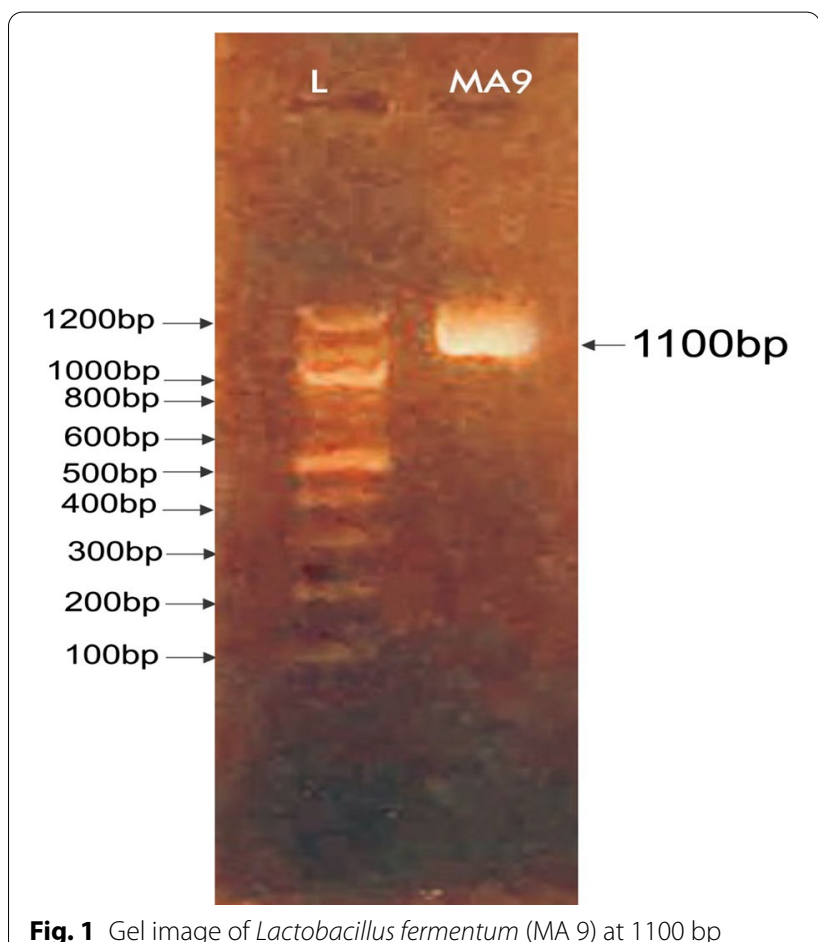

\section{Polymerase chain reaction (PCR) amplification of bacterial} 16S rDNA

Each PCR mixture consisted of $5 \mu \mathrm{l}$ master mix, $1 \mu \mathrm{l}$ of 10 pmol each of 27F-AGAGTTTGATCCTGGCTCAG and 1492R-GGTTACCTTGTTACGACTT (Lane 1991), $1 \mu \mathrm{l}$ DNA template and $17 \mu \mathrm{l}$ sterile nuclease-free water to make up to a total reaction of $25 \mu$ l. PCR amplification was carried out in an Applied Biosystem 2720 thermocycler. The mixture was subjected to an initial denaturation at $94{ }^{\circ} \mathrm{C}$ for $3 \mathrm{~min}$, followed by 35 cycles at $94{ }^{\circ} \mathrm{C}$ for $45 \mathrm{~s}$, $55^{\circ} \mathrm{C}$ for $60 \mathrm{~s}, 72{ }^{\circ} \mathrm{C}$ for $60 \mathrm{~s}$ and a final extension at $72{ }^{\circ} \mathrm{C}$ for $10 \mathrm{~min}$. Amplifications were visualized by electrophoresis on $1 \%$ agarose gel after staining with ethidium bromide (Hengstmann et al. 1999).

\section{Deoxyribonucleic acid (DNA) sequencing}

16S rDNA PCR product was extracted from gel extraction kit QIAquick (Qiagen) and was cloned using TA cloning kit (Invitrogen, San Diego, Calif.) as recommended by the manufacturer. DNA sequencing was conducted using ABI Prism BigDye ${ }^{\mathrm{TM}}$ Terminator cycle sequencing Ready Reaction Kit according to instructions of manufacturer (PE Applied Biosystems) ABI PrismTM 377XL DNA Sequencer (PerkinElmer) (Gomaa and Momtaz 2007).

The evolutionary history was inferred using the neighbour-joining method (Saitou and Nei 1987). The 
optimal tree with the sum of branch length $=9.87710978$ is shown. The tree is drawn to scale, with branch lengths in the same units as those of the evolutionary distances used to infer the phylogenetic tree. The evolutionary distances were computed using the maximum composite likelihood method (Tamura et al. 2017) and are in the units of the number of base substitutions per site. The analysis involved nine nucleotide sequences. Codon positions included were $1 \mathrm{st}+2 \mathrm{nd}+3 \mathrm{rd}+$ noncoding. All positions containing gaps and missing data were eliminated. There were a total of 1121 positions in the final dataset. Evolutionary analyses were conducted in MEGA7 (Kumar et al. 2014).

\section{Standardization of inoculum}

Standardization of inoculums was carried out using McFarland standard by preparing normal saline with the addition of $0.085 \mathrm{~g}$ of $\mathrm{NaCl}$ to $100 \mathrm{ml}$ of sterile distilled water in a 250-ml Erlenmeyer flask. Five millilitres of the normal saline was dispensed severally into test tubes and autoclaved at $121{ }^{\circ} \mathrm{C}$ for $15 \mathrm{~min}$. A mixture of $0.05 \mathrm{ml}$ of $1 \% \mathrm{BaCl}_{2}$ and $9.95 \mathrm{ml}$ of $1 \% \mathrm{H}_{2} \mathrm{SO}_{4}$ in $100 \mathrm{mls}$ of sterile distilled water served as McFarland standard. A 24-hold pure culture of the bacteria with the highest growth was inoculated into the normal saline, and the turbidity was compared with that of the McFarland standard in the presence of good lighting. The turbidity of the bacterial suspension with the highest growth was adjusted until it matches that of the McFarland standard.

\section{Linamarase production and assay}

The minimal medium used for this assay consists of $\mathrm{NaCl}$ 0.3\%; $\left(\mathrm{NH}_{4}\right)_{2} \mathrm{SO}_{4}$ 0.1\%; $\mathrm{KH}_{2} \mathrm{PO}_{4}$ 0.05\%; $\mathrm{MgSO}_{4}$ 0.02\%; $\mathrm{CaCl}_{2} \quad 0.02 \%$; lactose $3 \%$ and $\mathrm{KCN} 0.15 \%$ (Okafor and Ejiofor 1985). One hundred millilitres of the minimal medium in a $250-\mathrm{ml}$ Erlenmeyer flask was sterilized at $121^{\circ} \mathrm{C}$ for $15 \mathrm{~min}$ and adjusted to $\mathrm{pH} 5.5$ with sterile $\mathrm{HCl}$. Ten millilitres of cells suspension of the bacteria with the highest growth was transferred into the minimal medium and incubated for $24 \mathrm{~h}$ on a rotatory incubator $2500 \mathrm{rpm}$ for $30 \mathrm{~min}$ at $30{ }^{\circ} \mathrm{C}$. Cells were harvested by centrifugation, and the supernatants obtained were combined and used for enzyme assay.

\section{Assay procedures}

Linamarase activity was carried out by determining the $\mathrm{HCN}$ liberated from $\mathrm{KCN}$ as follows: $0.5 \mathrm{ml}$ of enzyme solution in $0.2 \mathrm{M}$ phosphate buffer $(\mathrm{pH}$ 6.5) contained in Eppendorf tubes was added to $0.5 \mathrm{ml}$ of $1 \mathrm{mM}$ buffered solution of $\mathrm{KCN}$ and incubated at $32{ }^{\circ} \mathrm{C}$ for $20 \mathrm{~min}$. Two millilitres of $2 \% \mathrm{KOH}$ and $1 \mathrm{ml}$ of sodium alkaline picrate were added into the reaction mixture, and the reaction was stopped by placing the tubes in iced water.
The red colour that developed was read at $540 \mathrm{~nm}$ in a spectrophotometer under the above conditions; one unit of activity was defined as the amount of enzyme that released $1 \mu \mathrm{g} \mathrm{HCN}$ in 30 min under assay condition (Nwokoro 2016).

\section{Effect of different cultural conditions on linamarase activity Determination of the effect of different inoculums volume on growth and linamarase activity}

Effect of inoculums volume on growth and linamarase activity was determined by dispensing $250 \mathrm{ml}$ of minimal medium containing $\mathrm{NaCl} 0.3 \%$; $\left(\mathrm{NH}_{4}\right)_{2} \mathrm{SO}_{4} 0.1 \% ; \mathrm{KH}_{2} \mathrm{PO}_{4}$ 0.05\%; $\mathrm{MgSO}_{4}$ 0.02\%; $\mathrm{CaCl}_{2}$ 0.02\%; lactose $3 \%$ and $\mathrm{KCN}$ $0.15 \%$ separately into four different Erlenmeyer flasks and sterilized at $121{ }^{\circ} \mathrm{C}$ for $15 \mathrm{~min}$. One hundred ppm of filter-sterilized $\mathrm{KCN}$ was added to the sterilized medium and inoculated with different volumes (cell suspension) of the bacterial cells with the highest growth $(0.05,0.1,0.15$ and $0.2 \mathrm{mls}$ ) and incubated on a rotatory shaker at $30^{\circ} \mathrm{C}$ for $96 \mathrm{~h}$. Ten millilitres of the medium was taken at 12-h intervals and centrifuged at $2500 \mathrm{rpm}$ for $40 \mathrm{~min}$. The cell growth was measured using spectrophotometer, and the supernatant was used for enzyme assay as described above. The experiment was carried out in triplicate.

\section{Determination of the effect of different $\mathrm{pH}$ on growth and linamarase activity}

Effect of $\mathrm{pH}$ on growth and linamarase activity was investigated by adjusting the $\mathrm{pH}$ of sterile MRS medium to $\mathrm{pH}$ 4.0, 4.5, 5.0, 5.5, 6.0 and 6.5. One hundred millilitres of MRS medium in a 250-ml Erlenmeyer flask was sterilized, and $100 \mathrm{ppm}$ of filter-sterilized KCN was added to the medium and inoculated with the optimum volume. Incubation was done on a rotatory shaker at $30{ }^{\circ} \mathrm{C}$ for $96 \mathrm{~h}$. Ten millilitres of the medium was taken at 12-h intervals and centrifuged at $2500 \mathrm{rpm}$ for $40 \mathrm{~min}$. The cell growth was measured using spectrophotometer, and the supernatant was used for enzyme assay as described above. The experiment was carried out in triplicate (Adeleke et al. 2017).

\section{Determination of the effect of different temperatures on growth and linamarase activity}

In order to determine the effect of different temperatures on growth and linamarase activity, $50 \mathrm{mls}$ of sterile MRS medium with $\mathrm{pH}$ adjusted to optimum $\mathrm{pH}$ was dispensed into sterile screw-capped Erlenmeyer flasks and sterilized at $121{ }^{\circ} \mathrm{C}$ for $15 \mathrm{~min}$ and $100 \mathrm{ppm}$ of filter-sterilized $\mathrm{KCN}$ was added and inoculated with 24-h-old culture of the bacteria with the highest growth using the optimum inoculums volume, $\mathrm{pH}$ and incubated separately at $10{ }^{\circ} \mathrm{C}, 20^{\circ} \mathrm{C}, 37^{\circ} \mathrm{C}, 45^{\circ} \mathrm{C}$ and 
$60{ }^{\circ} \mathrm{C}$ for $1 \mathrm{~h}$. Ten millilitres of the medium was taken at 12-h intervals and centrifuged at $2500 \mathrm{rpm}$ for $40 \mathrm{~min}$. The cell growth was measured using spectrophotometer, and the supernatant was used for enzyme assay as described above. The experiment was carried out in triplicate (Adeleke et al. 2017).

\section{Determination of the effect of incubation period on growth and linamarase activity}

The effect of incubation period on the growth and linamarase activity was studied by obtaining $100 \mathrm{mls}$ of sterile MRS broth with $\mathrm{pH}$ adjusted to optimum $\mathrm{pH}$ and dispensed into a 250-ml Erlenmeyer flask and sterilized at $121^{\circ} \mathrm{C}$ for 15 min with 100 ppm of filter-sterilized $\mathrm{KCN}$ added and inoculated with a 24-h-old culture of the bacteria with the highest growth using optimum inoculums volume, $\mathrm{pH}$ and temperature and incubated for $96 \mathrm{~h}$. Ten millilitres of the medium was taken at 12-h intervals and centrifuged at $2500 \mathrm{rpm}$ for $40 \mathrm{~min}$. The cell growth was measured using spectrophotometer, and the supernatant was used for enzyme assay as described above. The experiment was carried out in triplicate.

\section{Effect of substrate concentration on growth and linamarase activity}

Different concentrations of filter-sterilized KCN (100 ppm, 150 ppm, 200 ppm, 400 ppm, 500 ppm and $800 \mathrm{ppm}$ ) were prepared and added separately to MRS broth adjusted to optimum $\mathrm{pH}$ and sterilized at $121{ }^{\circ} \mathrm{C}$ for $15 \mathrm{~min}$. The sterilized medium was inoculated with a 24-h-old culture suspension of the bacteria with the highest growth using the optimum inoculums volume, $\mathrm{pH}$ and temperature incubation period. Ten millilitres of the medium was taken at 12 -h intervals and centrifuged at $2500 \mathrm{rpm}$ for $40 \mathrm{~min}$. The cell growth was measured using spectrophotometer, and the supernatant was used for enzyme assay as described above. The experiment was carried out in triplicate (Adeleke et al. 2017).

\section{Influence of different cations on growth and linamarase activity}

Five $\mathrm{mM}$ of various metal ions $\left(\mathrm{Hg}^{2+}\right.$, Urea, $\mathrm{NH}_{4}{ }^{+}, \mathrm{Ca}^{2+}$, $\mathrm{K}^{+}, \mathrm{Na}^{+}, \mathrm{Mg}^{2+}$ and $\mathrm{Fe}^{3+}$ ) was added to enzyme solution and incubated for $30 \mathrm{~min}$ at $37{ }^{\circ} \mathrm{C}$. Linamarase activity was measured by adding $\mathrm{KCN}$, and enzyme assay was carried out at optimum conditions. This was carried out in triplicates. Different concentrations of the best metal ion that stimulated the highest linamarase activity were prepared (5-25\%) and added to enzyme solution and incubated for $30 \mathrm{~min}$ at $37^{\circ} \mathrm{C}$.
Table 1 Results of microbial growth in minimum medium

\begin{tabular}{llll}
\hline MRS isolates & cfu/ml & NA isolates & cfu/ml \\
\hline MA 2 & $1.5 \times 10^{9}$ & NA 1 & $1.3 \times 10^{9}$ \\
MA 4 & $7.0 \times 10^{9}$ & NA 4 & $1.2 \times 10^{9}$ \\
MA 5 & $2.3 \times 10^{9}$ & NA 6 & $3.7 \times 10^{9}$ \\
MA 7 & $5.0 \times 10^{9}$ & NA 7 & $7.3 \times 10^{9}$ \\
MA 9 & $2.8 \times 10^{10}$ & NA 9 & $1.6 \times 1.0^{10}$ \\
MA 10 & $1.2 \times 10^{9}$ & NA 10 & $1.9 \times 10^{10}$ \\
MA 13 & $5.2 \times 10^{9}$ & NA 11 & $4.5 \times 10^{9}$ \\
MA 16 & $1.3 \times 10^{9}$ & NA 13 & $6.3 \times 10^{9}$ \\
MA 19 & $4.3 \times 10^{9}$ & NA 16 & $2.7 \times 10^{9}$ \\
MA 21 & $4.1 \times 10^{9}$ & NA 18 & $13 \times 10^{9}$ \\
\hline
\end{tabular}

Table 2 Safety assessment of the bacteria isolate (MA9) with the highest growth

\begin{tabular}{llll}
\hline Isolate code & Haemolysis & DNase & Gelatinase tests \\
\hline MA 9 & - & - & - \\
\hline,+ positive; - , negative & &
\end{tabular}

\section{Results}

Growth of isolated bacteria from cassava effluent in minimal medium

Table 1 shows the result of growth of isolated bacteria from cassava effluent in minimal medium. It was observed that MA9 had the highest growth of $2.8 \times 10^{10} \mathrm{cfu} / \mathrm{ml}$, while the lowest growth was observed with MA 10 with $1.2 \times 10^{9} \mathrm{cfu} / \mathrm{ml}$.

\section{Safety assessment of isolate MA 9}

Table 2 depicts the safe property of isolate MA9. It was revealed that the isolate tested negatively to all safety assessment and was regarded as safe.

\section{Biochemical and physiological characterizations of Isolate MA9}

The result of the phenotypic identification procedure of Isolate MA9 (isolate with the highest growth in the minimal medium) using physiological and biochemical characterizations is shown in Table 3. Isolate MA 9 is a Gram-positive, non-motile and non-spore-forming rod. It showed negative reactions to catalase, VP, methyl red, indole, and starch hydrolysis, oxidase positive but showed growth at $4 \%$ and $6 \% \mathrm{NaCl}$.

\section{Sugar fermentation pattern of Isolate MA9}

The result of sugar fermentation pattern of Isolate MA9 is shown in Table 4. It depicts that that isolate MA9 was able to degrade glucose, maltose, sucrose, fructose, 
Table 3 Biochemical and physiological characterizations of Isolate MA9

\begin{tabular}{|c|c|c|c|c|c|c|c|c|c|c|}
\hline Isolate code & Catalase test & Gram stain & Spore stain & $V p$ & Oxidase & $4 \% \mathrm{NaCl}$ & $6 \% \mathrm{NaCl}$ & Indole & Motility & Probable identity \\
\hline MA9 & - & + & - & - & + & + & + & - & - & Lactobacillus fermentum \\
\hline
\end{tabular}

+ , positive; - , negative

lactose, xylose, mannose, ribose, dextrose and raffinose. However, it did not utilize mannitol, galactose, sorbitol and rhamnose.

\section{Identification of Isolate MA9}

The combination of results in Tables 2 and 3 with reference to Bergey's Manual of Systematical Bacteriology was used to probably identify Isolate MA9 as Lactobacillus fermentum, while the molecular method was done using $16 \mathrm{~S}$ rDNA gene sequence analysis with a base pair of $1,100 \mathrm{bp}$ as shown in Fig. 1. The forward primer used was 27F-AGAGTTTGATCCTGGCTCAG, and the reverse primer was 1492R-GGTTACCTTGTTACGACTTT.

Identity of the isolate MA 9 was confirmed as Lactobacillus fermentum CIP 102960 using 16S rRNA analysis. The strain showed maximum similarity ratio towards $L$. fermentum CIP 102960 (98.02\%) accession number NR 104927 using NCBI data base (Fig. 2).

Figure 3 shows the result of the effect of different inoculums volume on the growth and linamarase activity of L. fermentum. The highest growth of 2.4980 OD and linamarase activity of $2.49 \mathrm{U} / \mathrm{ml}$ were observed at inoculums level of $0.10 \mathrm{ml}$ at 48 - $\mathrm{h}$ incubation period, while the least growth of $1.263 \mathrm{OD}$ and activity of $1.10 \mathrm{U} / \mathrm{ml}$ were observed at inoculums volume of $0.20 \mathrm{ml}$ at $72 \mathrm{~h}$.

\section{Effect of $\mathrm{pH}$ on growth and linamarase activity of $L$. fermentum}

The effect of $\mathrm{pH}$ on growth and linamarase activity of $L$. fermentum is presented in Fig. 4. It was observed that optimum growth of $1.926 \mathrm{OD}$ and linamarase activity of $1.66 \mathrm{U} / \mathrm{ml}$ occurred at $\mathrm{pH} 5.5$, while the least growth of $1.254 \mathrm{OD}$ and enzyme activity of $0.66 \mathrm{U} / \mathrm{ml}$ were recorded at $\mathrm{pH} 6.5$ and $\mathrm{pH} 4.0$, respectively.

\section{Effect of temperature on the growth and linamarase activity of $L$. fermentum}

The effect of temperature on the growth and linamarase activity of L. fermentum is shown in Fig. 5. The result revealed that an optimum growth of $0.38 \mathrm{OD}$ and enzyme activity of $1.18 \mathrm{U} / \mathrm{ml}$ were observed at $30{ }^{\circ} \mathrm{C}$. However, minimum growth of $0.13 \mathrm{OD}$ and enzyme activity of $0.39 \mathrm{U} / \mathrm{ml}$ were recorded at $60{ }^{\circ} \mathrm{C}$.
Effect of incubation period on growth and linamarase activity of $L$. fermentum

The effect of incubation period on growth and linamarase activity of $L$. fermentum is presented in Fig. 6. It revealed that L. fermentum showed optimum growth of 3.091 $\mathrm{OD}$ and enzyme activity of $1.81 \mathrm{U} / \mathrm{ml}$ at $48-\mathrm{h}$ incubation period, while minimum growth of $2.369 \mathrm{OD}$ and enzyme activity $0.97 \mathrm{U} / \mathrm{ml}$ occurred at $12 \mathrm{~h}$ of incubation.

\section{Effect of different substrate concentrations on the growth and linamarase activity of Lactobacillus fermentum}

Figure 7 showed the result of the effect of different substrate concentrations on the growth and linamarase activity of Lactobacillus fermentum. It can be inferred from the result that $L$. fermentum had the optimum growth of $2.783 \mathrm{OD}$ and linamarase activity of $1.86 \mathrm{U} / \mathrm{ml}$ at substrate concentration of $400 \mathrm{ppm}$, while least growth of $1.472 \mathrm{OD}$ and enzyme activity of $0.49 \mathrm{U} / \mathrm{ml}$ were recorded at $800 \mathrm{ppm}$ and $100 \mathrm{ppm}$, respectively.

\section{Effect of different metal ions on the activity of linamarase} The result of the effect of different metal ions on the activity of linamarase is shown in Fig. 8. The highest linamarase activity of $2.65 \mathrm{U} / \mathrm{ml}$ was stimulated by the supplementation of calcium ions in the assay medium, while the least activity of $0.43 \mathrm{U} / \mathrm{ml}$ was recorded with the supplementation of ammonium ions.

\section{Effect of varying concentrations of calcium ion on the linamarase activity of $L$. fermentum.}

Figure 9 shows the result of the effect of different concentrations of calcium ions on the linamarase activity of L. fermentum. The maximum activity of $3.42 \mathrm{U} / \mathrm{ml}$ was recorded with the supplementation of $10 \mathrm{mM}$ calcium ions, while the least activity of $2.54 \mathrm{U} / \mathrm{ml}$ was observed with the use of $25 \mathrm{mM}$ of calcium ions.

\section{Discussion}

This present study investigated the effect of cultural medium on the growth and production of linamarase by a local species isolated from cassava effluent identified as Lactobacillus fermentum. The isolation of lactic bacteria from effluent reported in this study has earlier been documented by Okafor et al. 1984; Amoa-Awua et al. (1996); Kobawila et al. (2005); Ayansina et al. (2015); Lacerda et al. (2005); and Adeleke et al. (2017). The survival 
Table 4 Sugar fermentation pattern of Isolate MA9

\begin{tabular}{|c|c|c|c|c|c|c|c|c|c|c|c|c|c|c|c|}
\hline $\begin{array}{l}\text { Isolate } \\
\text { code }\end{array}$ & Glucose & Maltose & Sucrose & Galactose & Sorbitol & Fructose & Lactose & Mannitol & Xylose & Mannose & Ribose & Dextrose & Rhamnose & Raffinose & $\begin{array}{l}\text { Probable } \\
\text { organism }\end{array}$ \\
\hline MA 9 & + & + & + & - & - & + & + & - & + & + & + & + & - & + & $\begin{array}{l}\text { Lactobacillu } \\
\text { fermentun }\end{array}$ \\
\hline
\end{tabular}

,+ positive; - , negative

of lactic bacteria in cassava effluent is due to their ability to tolerate the cyanide content present in the effluent and possession of linamarase enzyme capable of hydrolyzing the cyanide to simple end products which can be utilized for growth and metabolism by the bacteria (Offiong et al. 1990; Kostinek et al. 2006). Nwokoro (2016) reported the isolation and identification of a fast growing species of $L$. fermentum in a medium containing $800 \mathrm{mg} / \mathrm{l}$ potassium cyanide from fermenting cassava tuber. Equally in this study, the bacterium with the highest growth in minimal medium was identified using both phenotypic and molecular methods as L. fermentum; this result is supplementary to the submission of Nwokoro (2016).

The L. fermentum tested negative to all the safety assessments (gelatinase, DNase and haemolysis) which confirmed their safety property. There are earlier documented reports on the safety status of lactic acid bacteria which identify them as GRAS (generally regarded as safe) (Narvhus and Axelsson 2003). This unique property accords them acceptability as good starters in food fermentation.

The maximum linamarase activity was observed when the culture medium was inoculated with $0.1 \mathrm{ml}$ of inoculums volume, and further increase led to a decrease in enzyme activity. Similar observation had earlier been reported (Adeleke et al. 2017), and this occurrence might be due to increased competition for carbon and other nutrients. However, the increase in enzyme at lower inoculums volume is related to the presence of decreased number of cells for utilization of the substrate for desired product formation (Kashyap et al. 2002.) Inoculums volume plays a major role in enzyme activity by controlling and reducing the microbial lag phase (Iqbal et al. 2010).

In this present study, optimum linamarase activity was recorded at $\mathrm{pH}$ 5.5. This observation is in conformity with earlier findings of Gueguen et al. (1997) and Akinyele et al. (2014), and Maherawati et al. (2017) who reported $\mathrm{pH} 5.5$ for optimum production of $\beta$-glucosidase by Leuconostoc mesenteroides, cellulase by Aspergillus niger NSPRO12 in submerged fermentation and linamarase activity isolated from cassava leaves, respectively. However, Essen (1992) also reported pH 5.8 for optimum production of $\beta$-glucosidase, while Yeoh et al. (1995) observed that optimum linamarase activity of Aspergillus nidulans, Penicillium funiculosum and Fusarium oxysporum occurred at $\mathrm{pH}$ 5.1, 4.8 and 4.2, respectively. In addition, Bodade et al. (2010) explained that change in $\mathrm{pH}$ might result in morphological changes of the microorganism and decrease in enzyme secretion, thereby affecting enzyme activity. The $\mathrm{pH}$ of growth medium plays an important role in enzyme induction and production, and slight change in $\mathrm{pH}$ drastically influences microbial growth and enzyme production (Horikoshi 1971; Gurudeeban et al. 2011; Joshi and Yadav 2016). From the results obtained in this study, it can be inferred that $L$. fermentum prefers acidic $\mathrm{pH}$ for its optimum linamarase activity and it could be employed for the hydrolysis of cyanide in cassava fermentation which occurs naturally within a $\mathrm{pH}$ range of 5.5-5.8 (Nwokoro and Onyebuchi 2011). In addition, Joshi and Yadav (2016) observed that alteration in hydrogen concentration will lead to inhibition of the active site causing a reduction in enzyme activity, while Maherawati et al. (2017) emphasized that alteration in $\mathrm{pH}$ will alter the ionization prototropic group in the active site of the enzyme which will ultimately influence enzyme activity.

In this present study, optimum incubation temperature for linamarase activity occurred at $30{ }^{\circ} \mathrm{C}$. This finding corroborates the earlier report of Okafor and Ejiofor (1985) who reported that optimum activity for linamarase activity of yeast species was recorded at $29 \pm 2{ }^{\circ} \mathrm{C}$. However, Nwokoro and Onyebuchi (2011) reported optimum linamarase production by Lactobacillus delbrueckii at $50{ }^{\circ} \mathrm{C}$ which contradicts our findings in this work. $L$. fermentum may be suggested to be a mesophile and prefers a low temperature for its optimum enzyme activity (Maheshwari et al. 2000). However, this phenomenon seems to be strain dependent ( $\mathrm{Lu}$ et al. 2003; Gautam et al. 2010) and the occurrence of optimum linamarase activity of bacteria at low temperature hinders its application in biotechnological processes (Nwagu and Okolo 2011). It could be suggested that the application of linamarase in the detoxification of cassava should be done at low temperature range. Maherawati et al. (2017) explained that the stability of enzyme is a function of parameters such as temperature, $\mathrm{pH}$, ionic strength, presence of substrate, concentration of enzyme, proteins in the system, incubation time and presence of activators and inhibitor. In addition, an increase in temperature leads to an increase in kinetic energy which causes denaturation and destabilization of thermostable threedimensional structure of the enzyme at high temperature 


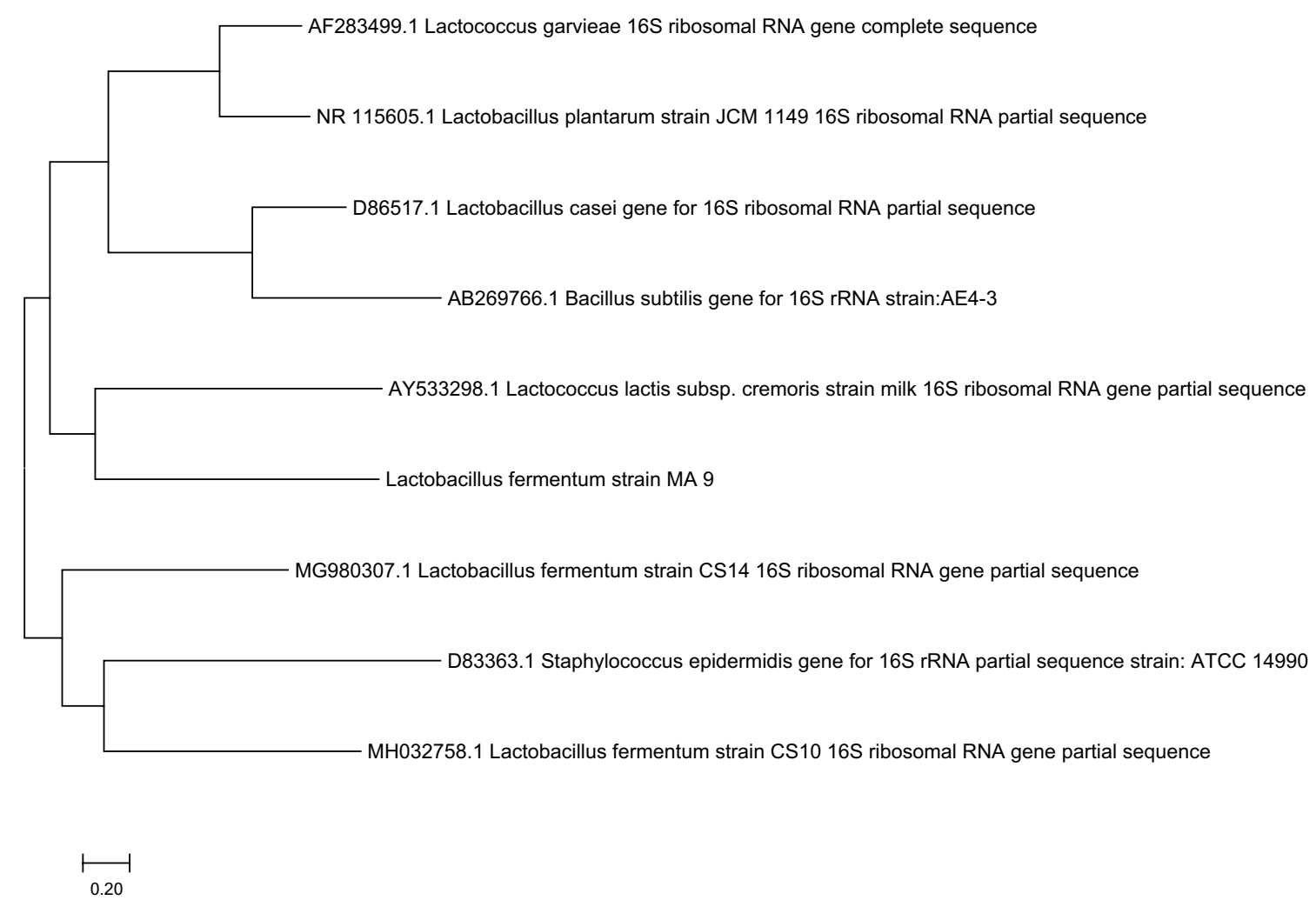

Fig. 2 Phylogenetic tree

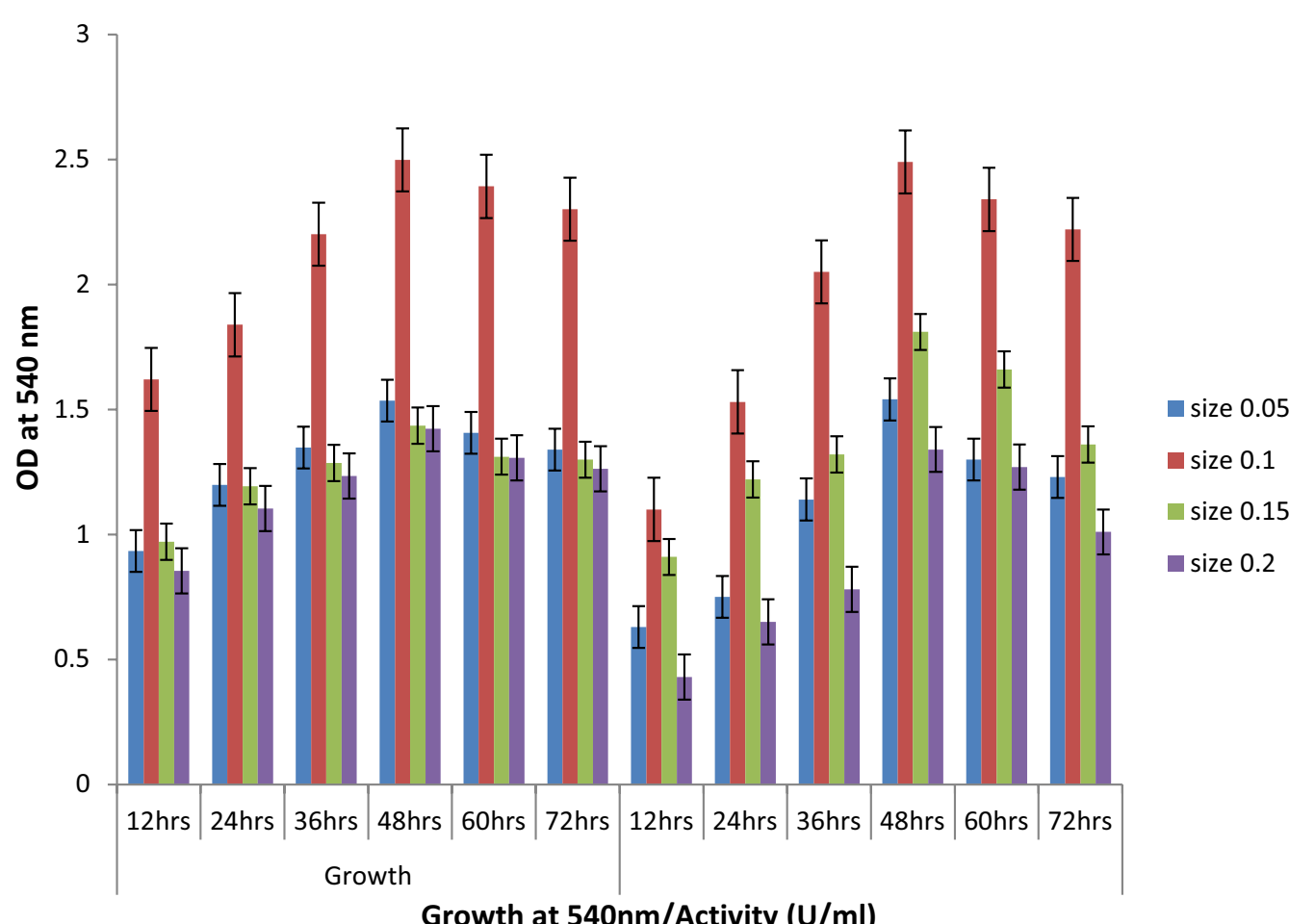

Fig. 3 Effect of inoculum volume on growth and enzyme activity of Lactobacillus fermentum at different incubation periods 


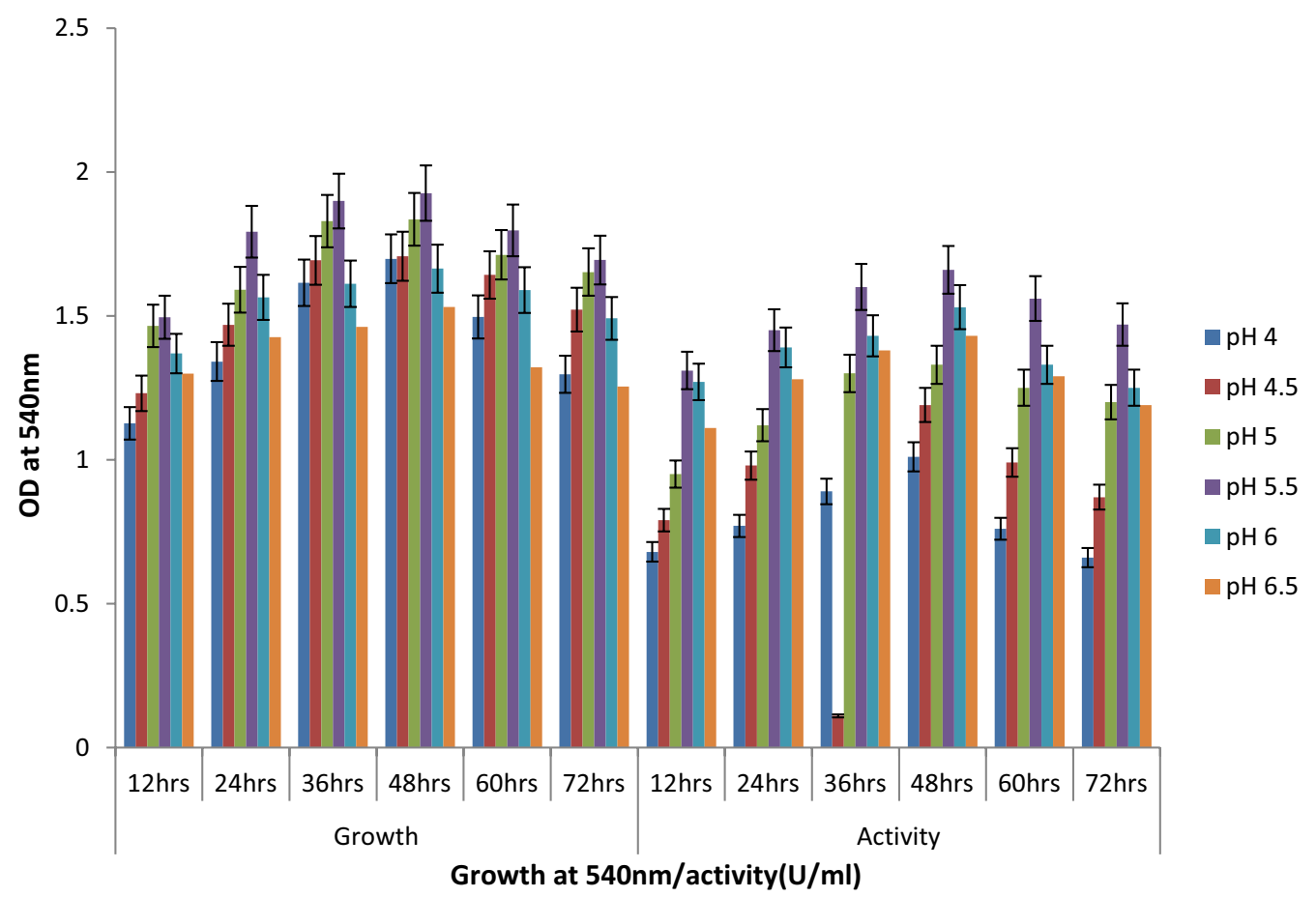

Fig. 4 Effect of $\mathrm{pH}$ on growth and linamarase activity of L. fermentum

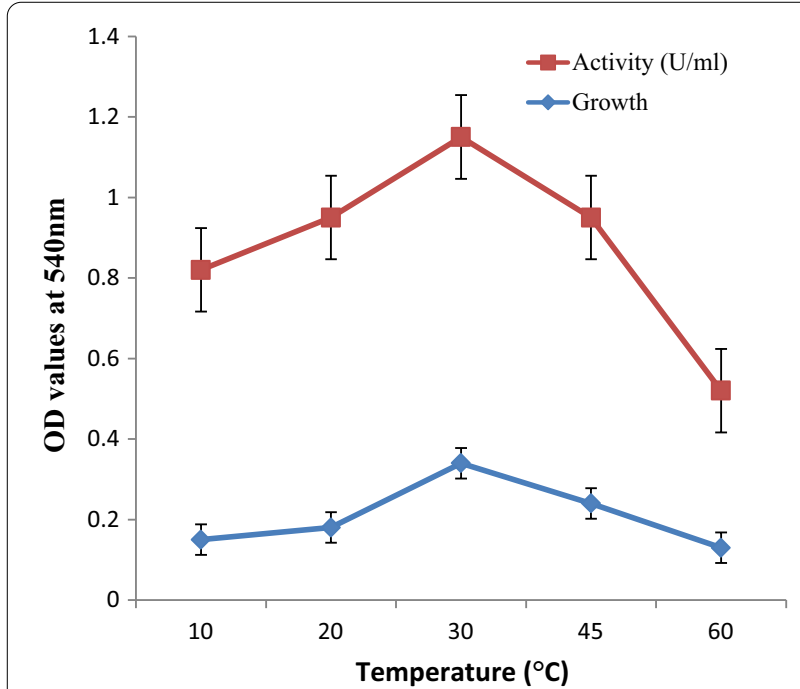

Fig. 5 Effect of temperature on the growth and linamarase activity of L. fermentum

(Bisswanger 2014). However, Petrucciolli et al. (1999) and Nwokoro and Onyebuchi (2011) reported that optimal linamarase activity of Mucor circinelloides and $L$. delbrueckii occurred at $40{ }^{\circ} \mathrm{C}$ and $50{ }^{\circ} \mathrm{C}$, respectively, which is at variance with our findings in this investigation. It is pertinent to report that each enzyme has its

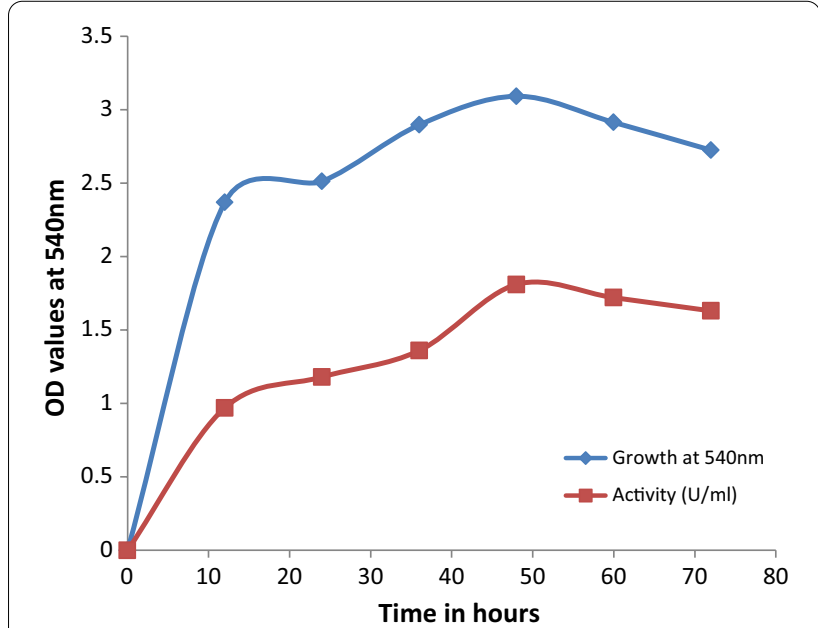

Fig. 6 Effect of incubation period on growth and linamarase activity L.fermentum

own optimum temperature for activity which is dependent on the strength of amino acids as monomers of enzymes (Maherawati et al. 2017). Nwagu and Okoli (2011) and Joshi and Yadav (2016) reported that optimal temperature is a paramount factor which affects microbial growth, stability, enzyme induction and production. The effect of incubation period on the activity 


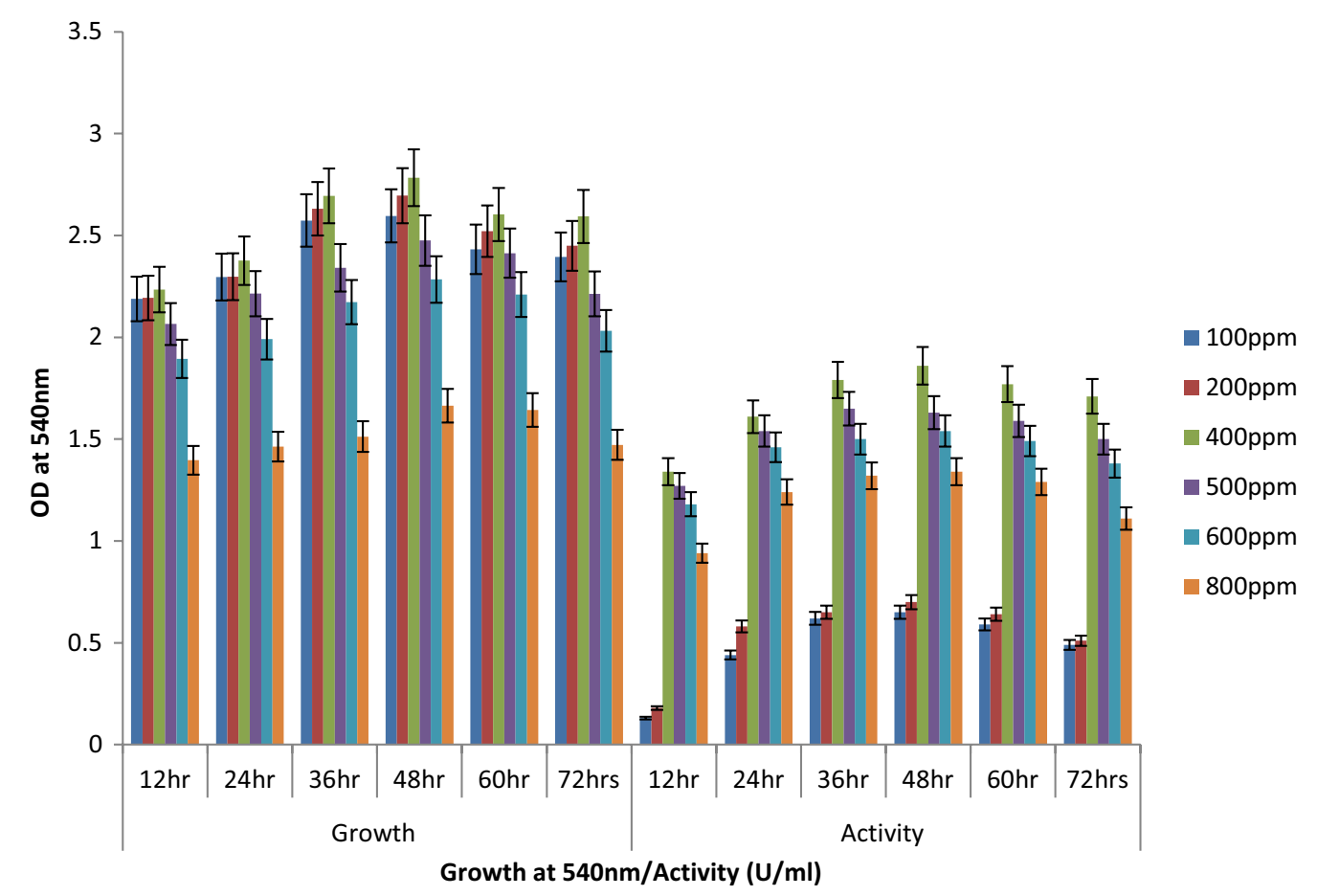

Fig. 7 Effect of substrate concentration on growth and linamarase activity of L. fermentum

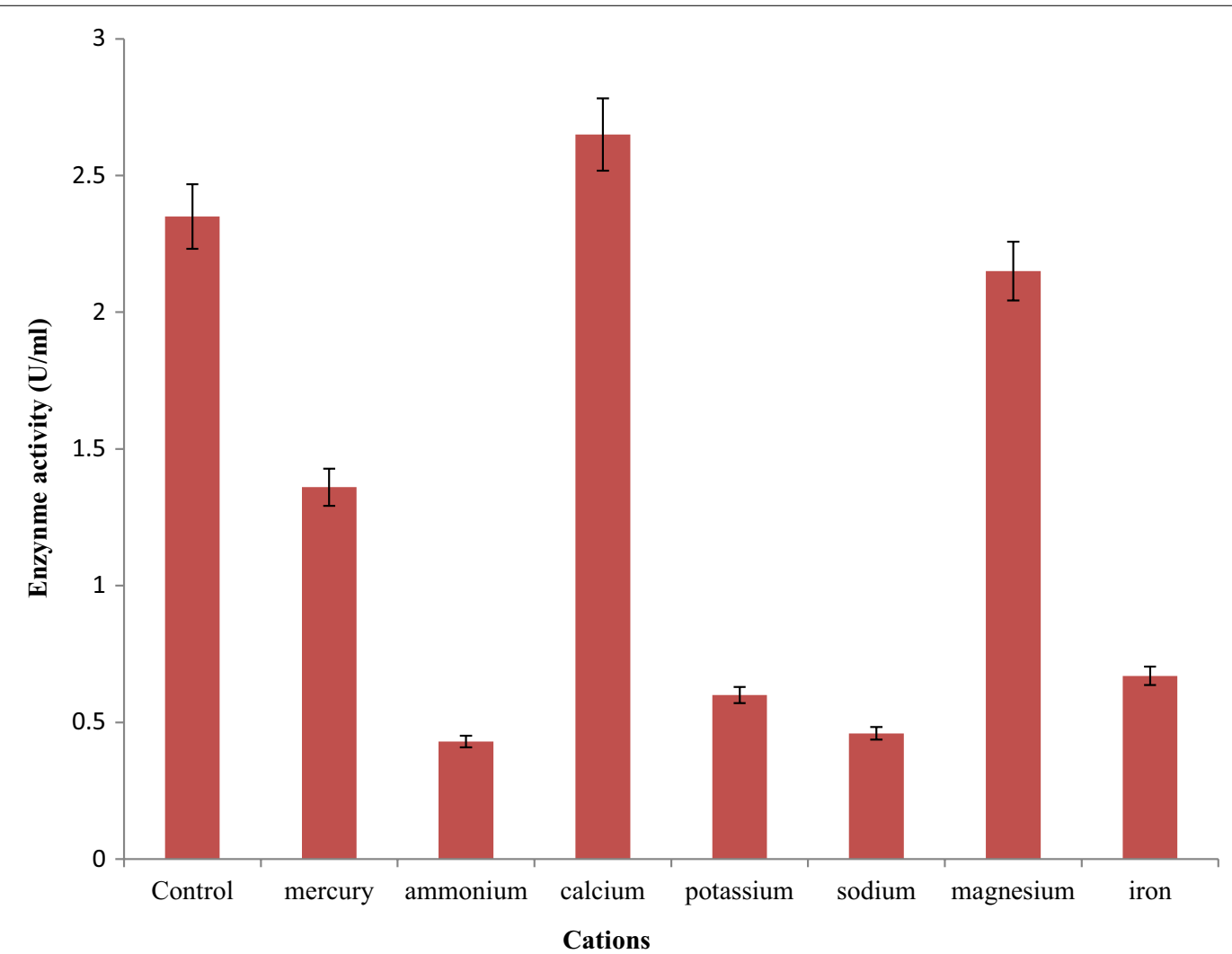

Fig. 8 Effect of different cations on linamarase activity of L. fermentum 


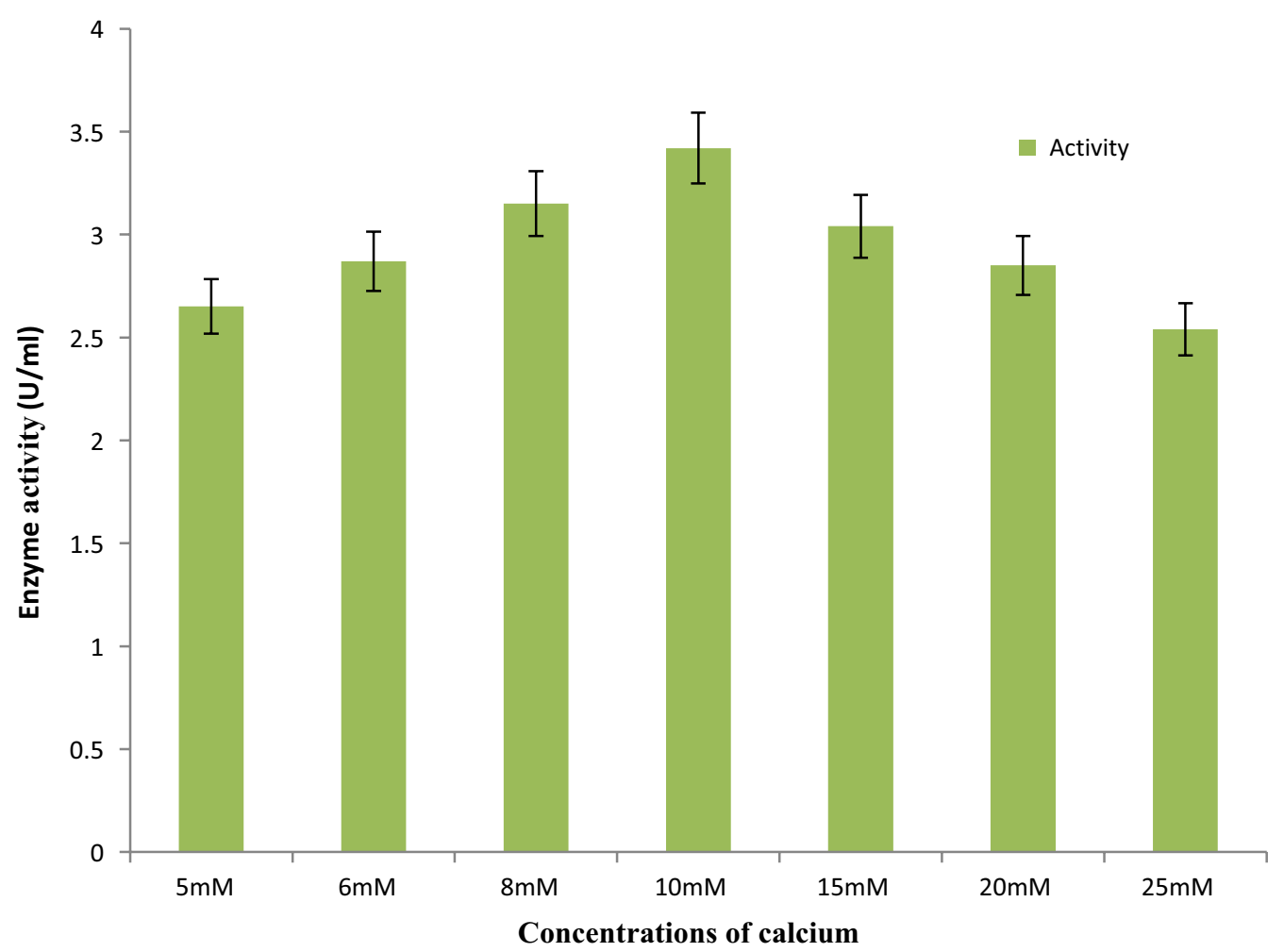

Fig. 9 Effect of different concentrations of calcium on enzyme production

of linamarase by L. fermentum showed that linamarase activity increased during the growth phase of the culture, reaching the optimum incubation time at $48 \mathrm{~h}$, and any further increase beyond this period resulted in lower activity. This observation is similar to the findings of Sakthivel et al. (2010) and Rezvani et al. (2016). Reason such as enormous utilization of the accessible part of the substrate which is needed for enzyme production thus leaving the unutilized crystalline portion which cannot be consumed by the bacteria for growth and enzyme production could be adduced to be responsible for this phenomenon (Omojasola et al. 2008). In addition, reduction in enzyme activity after $48 \mathrm{~h}$ might be caused by the bacteria transiting to the stationery phase of growth when cells are metabolically inactive. However, Adeleke et al. (2017) reported that optimum linamarase activity of L. plantarum was recorded at $22 \mathrm{~h}$ of incubation which contradicts our findings in this study. The effect of substrate concentration on the production of linamarase by L. fermentum showed that enzyme production increased as substrate concentration increased. Optimum substrate concentration attained a substrate concentration of 400 ppm, whereby enzyme activity ceased to rise regardless of any increase in substrate level. Reasons such as environmental saturation by the substrate occurred, whereby all enzymes are bound and reacting (Vmax) can be adduced for this occurrence. Similar finding had earlier been reported by Irshad et al. (2013) from an investigation carried out on the production of cellulose. It could be suggested that scaling up of linamarase production by $L$. fermentum could be achieved with 400 ppm substrate concentration (Sakthivel et al. 2010). In addition, Teodoro and Martins (2000) explained that the presence of available substrate has been reported to influence the biosynthesis of many extracellular enzyme via catabolic repression mechanism. In addition, Mamo and Gessesse (1999) explained that the reduction in enzyme activity with an increase in substrate concentration might be caused by end product repression of enzyme production and high viscosity of the medium leading to reduction in oxygen availability (Omidiji et al. 1997). According to Hafiz et al. (2010), substrate concentration is a crucial factor that influences the yield and initial hydrolysis of substrate.

In the present study, $\mathrm{Ca}^{2+}$ was observed to stimulate the highest linamarase activity when supplemented in the assay medium. This observation is in conformity with the submissions of Mishra and Maheswari (1996) and Adeleke et al. (2017). According to Lin et al. (1999) and Caiming et al. (2018), $\mathrm{Ca}^{2+}$ improves the thermostability 
of enzyme which is in alignment with the documented findings of Pandey et al. (2000) and the reasons for this phenomenon are ambiguous, but it is obvious that metal ions often act as ion bridge between two adjacent amino acids residue, thereby contributing to stimulatory potential of the metal ions on enzyme activity (Lin et al. 1999). The thermostability of enzyme is well documented. According to previous report, $\mathrm{Ca}^{2+}$ serves as protection against high temperature in thermostable enzyme (Violet and Meunier 1989; Savehenko et al. 2002). In addition, $\mathrm{Ca}^{2+}$ had been reported to stabilize total structure of the enzyme and also maintain structural integrity (Robyt 1984; Krishnan and Chandra 1989; Vihinen and Mantsala 1990; Violet and Meunier 1989; Ptacek et al. 2018) and its omission in the production medium will bring about reduction in enzyme activity (Machius et al. 1995). It can be suggested that linamarase is a metalloenzyme due to the occurrence of $\mathrm{Ca}^{2+}$ binding site for its activity and stability (Nwagu and Okolo 2011).

\section{Conclusion}

This research showed that linamarase production by $L$. fermentum can be optimized by considering parameters such as inoculums volume of $0.1 \mathrm{ml}, \mathrm{pH} 5.5$, temperature of $30{ }^{\circ} \mathrm{C}, 48$-h incubation period, substrate concentration of $400 \mathrm{ppm}$ and $10 \mathrm{mM}$ of calcium ion. It can be suggested that $L$. fermentum could be used as starter cultures in the fermentation of cassava for the production of cassava-based products with reduced cyanide content.

\section{Abbreviations \\ OD: Optical density; ATP: Adenosine triphosphate; PCR: Polymerase chain reaction; MRS agar: De Man, Rogosa and Sharpe agar; FCPD: Fibrocalculous pancreatic diabetes; GRAS: Generally regarded as safe.}

\section{Acknowledgements}

Not applicable.

\section{Authors' contributions}

IFF designed, conceptualized and supervised the study. BNK and OSF carried out the experimental protocols and assays. IFF wrote the first draft. The authors read and approved the final manuscript.

\section{Funding}

This research was self-funded.

\section{Availability of data and materials}

All data generated or analyzed during this study are included in this article.

Ethics approval and consent to participate

Not applicable.

\section{Consent for publication}

Not applicable.

\section{Competing interests}

No competing interest exists in the research outcome presented in this article.

\section{Author details}

${ }^{1}$ Department of Microbiology, Faculty of Science, University of Ibadan, Ibadan, Oyo State, Nigeria. ${ }^{2}$ Department of Biochemistry, Faculty of Basic Medical Science, Ladoke Akintola University of Technology, Ogbomosho, Oyo State, Nigeria. ${ }^{3}$ Department of Biochemistry, College of Bioscience, Federal University of Agriculture, Abeokuta, Ogun State, Nigeria.

Received: 30 July 2020 Accepted: 18 October 2020

Published online: 02 November 2020

\section{References}

Abban S, Brimer L, Warda S, Abdelgadir M, Jakobsen M, Thorsen L (2013) Screening for Bacillus subtilis isolate that degrades cyanogens at $\mathrm{pH}$ 4.5-5.0. Int J Food Microbiol 16(1):31-35

Adeleke BS, Olaniyi OO, Akinyele BJ (2017) Isolation and screening of bacteria associated with fermented cassava peels for linamarase production. Int J Appl Microbiol Biotechnol Res 5:20-26

Ahaotu I, Ogueke CC, Owuamanam Cl, Ahaotu NN, Nwosu JN (2013) Protein improvement in gari by the use of pure cultures of microorganisms involved in the natural fermentation process. Pak J Biol Sci 14(20):933-938

Akinjogunla OJ, Ajayi AO, Ekeh NO (2014) Virulence factors and antibiotic resistant Staphylococcus spp. from the anterior nares of apparently healthy undergraduate students in Uyo. Am J Res Commun 2(11):158-180

Akinyele JB, Falade OE, Olaniyi OO (2014) Screening and optimization of cultural conditions for cellulose production by Aspergillus niger NSPRO in submerged fermentation. J Microbiol Biotechnol Food Sci 4(3):189-193

Amoa-Awua WKA, Appoh F, Jakobsen M (1996) Lactic acid fermentation of cassava into agbelima. Int J Food Microbiol 31:87-98

Ayansina AD, Garuba EO, Baba J (2015) Some physico-chemical parameters and major microorganisms isolated from cassava waste water and a receiving nearby stream. Int J Curr Microbiol Appl Sci 4(6):211-217

Bisswanger H (2014) Enzyme assays. Enzyme Perspect Sci 1:41-55

Bodade GR, Chandarahas N, Arfeen SA (2010) Optimization of culture conditions for glucose oxidase production by a Penicillium chrysogenum SRT 19 strain. Engl J Life Sci 10(1):35-39

Caiming L, Shuangdi C, Zhengbiao G, Yan H, Li C, Zhaofeng L (2018) Enhancement of a-CGTase thermostability with the addition of calcium or barium ions. Food Biosci 26:139-144

Cardoso P, Mirione E, Ernesto M, Massaza F, Cliff J, Haque M, Bradbury J (2005) Processing of cassava roots to remove cyanogens. J Venomous Anim Toxins 18:451-456

Cheesbrough M (2006) District laboratory practice in tropical countries, part 2. Cambridge University Press, Cambridge, pp 47-54

Cooke RD (1978) An enzymatic assay for the total cyanide content of cassava (Manihot esculentaCrantz). J Sci Food Agric 29:345-352

Dunstan WR, Henry TA, Auld SJM (1996) Cyanogenesis in plant. The occurrence of phaseolunatin in cassava (Manihot aipi and Manihot utilissima. Proc R Doc Lond 78:152-158

Essen A (1992) Purification and partial characterization of maize (Zea mays) ß-glucosidase. Plant Physiol 98(1):174-182

Gautam SP, Budela PS, Pandey AK, Jamaluddin ANK, Sarsaiya S (2010) Optimization of the medium for the production of cellulose by Trichoderma viridie using submerged fermentation. Int J Environ Sci 4(1):656-665

Gomaa O, Momtaz O (2007) 16S rRNA characterization of Bacillus isolate and its tolerance profile after subsequent sub culturing. Arab J Biotechnol 10(1):107-116

Gueguen Y, Chemardin P, Labrot P, Arnaud A, Galzy PJ (1997) Purification and characterization of an intracellular glucosidase from a new strain of Leuconostoc mesenteroides isolated from cassava. Appl Microbiol 82:469-476

Gurudeeban S, Satyavani K, Ramanathan T (2011) Production of extracellular a-amylase using Bacillus megaterium isolated from white mangrove (Avicennia marina). Asian J Biotechnol 3(8):310-316

Hafiz MNT, Muhammad A, Ishiaq A, Shahbaz H (2010) Media optimization for hyper production of carboxy methyl cellulase using proximally analyzed 
agro industrial residue with Trichoderma harziamum under SSF. Int J Agro Vet Med Sci 4(2):47-55

Harrigan WF, McCance ME (1966) Laboratory methods in microbiology. Academic Press, London

Hengstmann U, Chin K, Janssen PH, Liesack W (1999) Comparative phylogenetic assignment of environmental sequences of gene encoding $16 \mathrm{~S}$ rRNA and numerically abundant culturable bacteria from anoxic rice paddy soil. Appl Environ Microbiol 5(11):5050-5058

Holt JG (1994) Bergey's manual of determinative bacteriology, 9th edn. Lippincott Williams and Wilkins, Baltimore

Horikoshi K (1971) Production of alkaline enzymes by alkalophilic microorganisms. Agric Biol Chem 35(9):1407-1414

Huertas MJ, Luque-Almagro VM, Martinez-Luque M, Blasco R, Moreno-Vivian C, Castillo F, Roldan MD (2006) Cyanide metabolism of Pseudomonas pseudoalcligens CECT5344: role of siderophores. Biochem Soc Trans 34(1):152-155

Ikediobi CO, Onyike E (1982) The use of linamarase in gari production. Process Biochem 101:847-854

Iqbal HMN, Asgher MA, Ahmed I, Hussein S (2010) Media optimization for hyper-production of carboxyl methyl cellulose using proximally analysed agro-industrial residue with Trichoderma harzanium under solid state fermentation. Int J Agro Vet Med Sci 4(2):47-55

Irshad M, Anwar Z, But HI, Afroz A, Ikram N, Rashi U (2013) The industrial applicability of purified cellulase complex indigenously produced by Trichoderma viridae through solid-state bio processing of agro-industrial and municipal paper wastes. Bioresearch 8(1):145-157

Joshi PA, Yadav A (2016) Optimization of cultural conditions and partial characterization of alkaline amylase from Bacillus. Int J Res Sci Innov 3(8):71-75

Kashyap P, Sabu A, Pandey A, Szakas G, Soccol CR (2002) Extracellular Lglutaminase production by Zygosaccharomyces rouxii under solid state fermentation. Process Biochem 38:307-312

Kobawila S, Louembe D, Keleke S, Hounhouigan J, Gamba C (2005) Reduction of the cyanide content during fermentation of cassava roots and leaves to produce bikedi and ntobambodi, two food products from Congo. Afr J Biotech 4(7):689-696

Kostinek M, Specht I, Edward A, Pinto C, Egounlety MC, Sossa CS, Mbugua S, Dortu C, Thonart P (2006) Characterization and biochemical properties of predominant lactic acid bacteria from fermenting cassava for selection as starter cultures. Int J Food Microbiol 114(3):342-351

Krishnan T, Chandra AK (1989) Purification and characterization of a-amylase from Bacillus licheriformis CUCM 305. Appl Environ Microbiol 46:430-437

Kumar Y, Singh PK, Singh AK, Mash AH, Kiran J, Benjamin JC, Rath S (2014) Production optimization of alpha amylase from Bacillus altitudinis. Int J Sci Eng Technol Res 3(4):654-673

Lacerda ICA, Miranda RL, Borelli BM, Nunes AC, Nardi RMD, Lachance MA, Rosa CA (2005) Lactic acid bacteria and yeast associated with spontaneous fermentations during production of sour cassava starch in Brazil. Int J Food Microbiol 105:213-219

Lane DJ (1991) 16S/23S rRNA sequencing. In: Stackebrandt E, Goodfellow M (eds) Nucleic acid techniques in bacterial systematics. Wiley, New York, pp 115-175

Lin CH, Chan FCH, Hwang JK, Lyu PC (1999) Calcium bindig mode of carboxglutamic acids in conantokins. Protein Eng 12(7):589-595

Lu WI, Li D, Wu Y (2003) Influence of water activity and temperature on xylanase biosynthesis in pilot scale solid state fermentation of Aspergillus sulphuros. Enzyme Microbiolo Technol 32:305-311

Machius M, Wiegand G, Huber R (1995) Crystalline structure of calciumdepleted Bacillus licheriformis X-amylase.22-A resolution. J Mol Biol 246:545-559

Maherawati M, Utami T, Prant Y, Cahyanto MN (2017) Activity and stability of linamarase from cassava (Manihot esculenta Crantz) leaves and its ability to hydrolyse linamarin. Int J Sci Technol 5(3):82-87

Maheshwari R, Bharadwaj G, Bhat MK (2000) Thermophilic fungi: their physiology and enzymes. Microbiol Mol Biol Rev 64:461-488

Mamo G, Gessesse A (1999) Effect of cultural conditions on growth and a-amylase production by a thermophilic Bacillus sp. Lett Appl Microbiol 20:61-65

Mathangi D, Deepa R, Mohan V, Govindarajan M, Namasivayam A (2000) Long term ingestion of cassava (tapioca) does not produce diabetes or pancreatitis in rat model. Int J Pancreatol 27:203-208
Mishra RA, Maheswari R (1996) Amylase of the thermophilic fungi Thermomyces lanuginosis- their purification, properties, action on starch and response to heat. J Biosci 21:653-672S

Murugan K, Yashota K, Saleh A (2012) Detoxification of cyanides in cassava flour by linamarase of Bacillus subtilis KM05 isolated from cassava peel. Afr J Biotech 11(28):7232-7237

Nartey F (1968) Studies on cassava, Manihotutilissima Pohl 1. Phytochemistry 7:1307-1312

Narvhus JA, Axelsson L (2003) Encyclopedia of food science and nutrition, 2nd edn. CRC Press, Cambridge

Nelson DL, Cox MM (2005) Lehninger principles of biochemistry, 4th edn. Freeman, New York, W.H

Nwagu TN, Okolo BN (2011) Extracellulase amylase production of thermotolerant Fusarium sp isolated from eastern Nigerian soil. Braz Arch Biol Technol 54:649-658

Nwokoro O (2016) Linamarase production by microbial isolates and degradation of cassava cyanide. Hemijska industrija 70(2):129-136

Nwokoro O, Onyebuchi A (2011) Linamarase Enzyme from Lactobacillus delbrueckii NRRL B-763: Purification and Some Properties of a $\beta$-Glucosidase. J Mex Chem Soc 55(4):246-250

Offiong EM, Hua Y, Grady C, Richard TS (1990) Purification, characterization and localization of linamarase in cassava. Plant Physiol 93:176-181

Okafor N, Ejiofor AO (1985) Rapid detoxification of cassava mash fermenting for gari production following inoculation with yeast simultaneously producing linamarase and amylase. Process Biochem 6:82-86

Okafor N, ljioma B, Oyolu C (1984) Studies on the microbiology of cassava retting for foo-foo production. J Appl Bacteriol 56:1-13

Omidiji O, Buraimoh OO, Ilori AA (1997) Production of a-amylase in a corn liquor- soya meal medium strain of Bacillus stearothemophilus. Microbios 90:155-162

Omojasola PF, Jilani OP, Ibiyemi SA (2008) Cellulase production by some fungi cultured on pineapple waste. Nat Sci 6(2):64-79

Owuamanam JO, Iwouno N, Ihediohanma C, Barber L (2010) Cyanide reduction, functional and sensory quality of Gari as affected by $\mathrm{pH}$, temperature and fermentation time. Pak J Nutr 9(10):980-986

Pandey AP, Nigram CR, Soccol D, Singh K, Mohan C (2000) Advances in microbial analysis. Biotechnol Appl Biochem 31:135-152

Petrucciolli M, Primer LR, Cicalini AR, Federici RR (1999) The linamarase of Mucor circinelloides LU M40 and its detoxifying activity on cassava. J Appl Microbiol 86:302-310

Ptacek J, Nedvedova N, Navratil M, Havlinova B, Konvalinka J, Barinka C (2018) The calcium-binding site of human glutamate carboxypeptidase II is critical for dimerization, thermal stability, and enzymatic activity. Protein Sci 27(9):1575-1585

Rezvani F, Ardestani F, Najafpour G (2016) Growth kinetic models of five species of Lactobacilli and lactase consumption in batch submerged culture. Braz J Microbiol 208:1-8

Robyt JF (1984) Enzyme in the hydrolysis and synthesis of starch. In: Whistler RL, Bemiller JN, Paschall EF (eds) Starch chemistry and technology, 2nd edn. Academic Press, New York, pp 88-90

Rolle RS (1998) Enzyme application of agro-processing in developing countries: an inventory of current and potential applications. World J Microbiol Biotechnol 14(5):611-619

Sakthivel M, Karthikeyan N, Jayanevy R, Palani P (2010) Optimization for cultural conditions for the production of extracellular cellulase from Corynebacteria lipophiloflavum. J Ecobiotechnol 2(9):6-13

Savehenko AC, Velle S, Kang G, Zeikus G (2002) Pyrococcus friosus a-amylase stabilized by calcium and znic. Biochemistry 41:6193-6201

Sneath PH (1986) Bergeys. Manual of systematic bacteriology. Williams and Wilkins, Baltimore

Tamura K, Stecker G, Peterson D, Filipski A, Kumar S (2017) MEGA A6: molecular evolutionary genetics version analysis 6.0. Mol Biol Evol 30:2725-2729

Tefera T, Ameha K, Biruhtesfa A (2014) Cassava based foods: microbial fermentation by single starter culture towards cyanide reduction, protein enhancement and palatability. Int Food Res J 21(5):1751-1756

Teodoro CES, Martins MLL (2000) Culture conditions for the production of thermostable amylase by Bacillus sp. Braz J Microbiol 31:298-302

Vihinen M, Mantsala M (1990) Characterisation of thermostable Bacillus stearothermophilus a- amylase. Biotechnol Appl Biochem 12:427-435

Violet M, Meunier JC (1989) Kinetic study of the irreversible thermal denaturation of Bacillus licheniformis a-amylase. Biochem J 263:665-670 
Woo PC, Leung KW, Tsoi HW, Wong SS, Teng JL, Yuen KY (2002) Thermotolerant Campylobacter fetus bacteraemia identified by $16 \mathrm{~S}$ ribosomal RNA gene sequencing: an emerging pathogen in immune compromised patients. J Med Microbiol 51:740-746

Yeoh HH, Tan TK, Loh CM (1995) Sources of fungal linamarase. World J Microbiol Biotechnol 11:678-680

\section{Publisher's Note}

Springer Nature remains neutral with regard to jurisdictional claims in published maps and institutional affiliations. 